Vasyl M. Trysnyuk, D. S. (Engineering), Senior Researcher

ORCID ID: 0000-0001-9920-4879e-mail: trysnyuk@ukr.net

Vyacheslav O. Okharev, $\mathrm{PhD}$, Senior Researcher

ORCID ID: 0000-0001-6270-6293 e-mail: okhariev.vo@gmail.com

Taras V. Trysnyuk, PhD, Senior Researcher

ORCID ID: 0000-0002-3672-8242e-mail: trysnyuktaras@ukr.net

Yuriy M. Holovan, postgraduate

ORCID ID: 0000-0001-7050-9310e-mail: dirrecta@gmail.com

Institute of Telecommunications and Global Information Space of NASU, Kyiv, Ukraine

\title{
SYSTEM OF ECOLOGICAL MONITORING OF PEDOSPHERE POLLUTION BY PETROLEUM PRODUCTS
}

\begin{abstract}
The article proposes a topical scientific-applied task of increasing the level of ecological safety of the soil cover contaminated with petroleum products. The main tasks are to develop new methods of environmental monitoring of soil cover; research on the processes of migration of petroleum products in the soil cover in order to improve the quality of the degradation of degraded territories and to develop forecast models for the timely identification of areas that are at risk of contamination; establishment of dependencies between the state of contamination of soils with petroleum products and their genesis and identification of patterns of propagation of the pollutant in the studied environment. In the course of the research, the system of ecological monitoring of the soil cover with the use of the infrared spectrophotometry method was improved. The method of physicochemical analysis of soil samples is substantiated and dependencies between the state of soil contamination of petroleum products and their genesis are established.
\end{abstract}

Keywords: petroleum products; soil cover; reclamation; pollution; degradation; monitoring

\section{В.М. Триснюк, В.О. Охарєв, Т.В. Триснюк, Ю.М. Голован}

Інститут телекомунікацій і глобального інформаційного простору НАН України, м. Київ, Україна

\section{СИСТЕМА ЕКОЛОГІЧНОГО МОНІТОРИНГУ ЗАБРУДНЕНННЯ ПЕДОСФЕРИ НАФТОПРОДУКТАМИ}

\begin{abstract}
Анотація. У статті запропоновано актуальне науково-прикладне завдання підвищення рівня екологічної безпеки трунтового покриву, забрудненого нафтопродуктами. Основні шляхи його розв'язання полягають у розробленні нових методів екологічного моніторингу трунтового покриву; дослідженні прочесів міграчії нафтопродуктів у трунтовому покриві з метою підвищення якості рекультивації деградованих територій та розробленні прогнозних моделей для своєчасного виявлення територій, які перебувають у зоні ризику забруднення; встановленні залежностей між станом забруднення трунтів нафтопродуктами та їх генезисом і виявленні закономірностей поширення
\end{abstract}

(C) В.М. Триснюк, В.О. Охарєв, Т.В. Триснюк, Ю.М. Голован, 2020 
полютанта $y$ досліджуваному середовищі. $B$ прочесі досліджень вдосконалено систему екологічного моніторингу трунтового покриву 3 застосуванням методу інфрачервоної спектрофотометрії. Обтрунтовано метод фізико-хімічного аналізу проб грунтів та встановлено залежності між станом забруднення трунтів нафтопродуктами та їх генезисом.

Ключові слова: нафтопродукти; трунтовий покрив; рекультивачія; забруднення; деградаиія; моніторинг

\section{Вступ}

Забруднення грунтового покриву залишилось актуальною проблемою навіть із зменшенням видобувного навантаження, а підтвердженням $є$ продовження деградації родючого шару, що завдає нищівної шкоди екосистемі. Аналізуючи роботи попередніх досліджень, була обгрунтована необхідність розробки системи сучасного екологічного моніторингу при нафтовому забрудненні та оптимального застосовування не лише досліджень рівня нафтохімічного забруднення та змін фізико-хімічних властивостей грунтів, а й екологічної оцінки, можливих перспектив для подальшого використання деградованих територій нафтових родовищ. Метою статті $€$ розроблення системи екологічного моніторингу грунтового покриву для виснажених нафтогазових родовищ 3 застосуванням методу інфрачервоної спектрофотометрії. Аналізуючи літературні джерела та наукові роботи, які пов'язані з проблемами моніторингу грунтового покриву забрудненої нафтопродуктами території, можна визначити основні завдання, які полягають у розробленні нових методів екологічного моніторингу грунтового покриву; дослідженні процесів міграції нафтопродуктів у грунтовому покриві 3 метою підвищення якості рекультивації деградованих територій та розробленні прогнозних моделей для своєчасного виявлення територій, які перебувають у зоні ризику забруднення; встановленні залежностей між станом забруднення грунтів нафтопродуктами та їх генезисом i виявленні закономірностей поширення полютанта у досліджуваному середовищі $[1,5]$.

\section{Виклад основного матеріалу дослідження}

Під час потрапляння у грунт нафтопродукти розподіляються інакше, ніж, наприклад, у водному середовищі. Якщо під час потрапляння у воду нафтопродукти утворюють тонку плівку, збіднюються леткими фракціями й далі утворюють емульсії, то у грунті вони проникають вглиб від поверхні, а збіднення леткими фракціями вуглеводнів відбувається значно меншою мірою. Нафтопродукти всмоктуються грунтом (особливо добре сухим грунтом) за рахунок капілярних сил й можуть утримуватися в такому стані тривалий час, повністю позбавляючи грунт родючості, перетворюючи його в насичену нафтопродуктами губку [5]. Моніторинг грунтів складається із систематичних спостережень за станом грунтів (зйомки, обстеження, вишукування), виявлення змін, а також оцінювання: стану використання угідь, полів, земельних ділянок; процесів, пов'язаних із зміною родючості грунтів (розвиток водної та вітрової ерозії, втрата гумусу, погіршення структури грунту, заболочення та засолення), заростання сільськогосподарських угідь, забруднення грунтів пестицидами та іншими токсичними речовинами; стану 
берегових ліній річок, озер, морів, заток, лиманів, водосховищ, гідротехнічних споруд; процесів, пов'язаних 3 утворенням ярів, зсувів, сольових потоків, карстових, кріогенних та інших явищ; стану грунтів населених пунктів, територій, зайнятих очисними спорудами, гноєсховищами, складами пальномастильних матеріалів, добрив, стоянками автотранспорту, захороненням токсичних промислових відходів і радіоактивних матеріалів, а також іншими промисловими об'єктами. Моніторинг земельних ресурсів неможливий без врахування взаємозв'язку із компонентами живої природи, особливою мірою це стосується прогнозування змін у структурі земельних ресурсів. Не менш вагомим $\epsilon$ вплив людського суспільства на структуру, стан та зміни земельних ресурсів. Особливо це актуально у сфері екології, збереження довкілля, раціонального природокористування та оптимізації максимальної ефективності використання природних ресурсів. Моніторинг земельних ресурсів виконується в усіх підсистемах геосфери із використанням усіх придатних для цього методів та технологій природничих та прикладних наук. Моніторинг земельних ресурсів здійснюють на трьох рівнях — національному, регіональному та локальному. Вважають, що грунти є забрудненими, коли концентрація нафти чи нафтопродуктів в них досягає такої величини, при якій починаються негативні зміни екологічного стану навколишнього природного середовища, включаючи гідро- і атмосферу. Небезпечним забруднення є тоді, коли воно перевищує границю потенціалу самоочищення. Встановлено, що при рівні вмісту нафтопродуктів в грунті до 100 мг/кг в ньому ще немає ознак екологічної шкоди, від 400 мг/кг - проявляється фітотоксична дія нафтозабруднення, від 2000 мг/кг - пригнічується мікробіоценоз, від 20000 мг/кг - починається повна деградація грунту [6]. Згідно 3 іншою класифікацією, яка базується на дослідженнях консорціуму мікроорганізмів нафтозабруднених грунтів, виділяють три якісно відмінні рівні забруднення [7]. 1. Низький (зона гомеостазу) із вмістом нафтопродуктів до 0,7 мл/кг (від 0,06 до $4,3 \%$ ); цей рівень забруднення характеризують незначні кількісні зміни мікробіологічних показників, котрі найчастіше несуттєво відрізняються від контрольних показників. 2. Високий (зона резистентності) - від 50 до 300 мл/кг (від 4,3\% до 25,5\%); у цьому разі спостерігається зміна домінантних форм. 3. Дуже високий (зона репресіі) - більше 300 мл/кг (більше 25,5\%); для цього рівня властиве майже повне пригнічення розвитку мікроорганізмів у грунті та інгібування мікробіологічних процесів [8]. Рівень допустимої концентрації нафти та нафтопродуктів у грунтах не скрізь однаковий. Він буде відрізнятися залежно від: грунтово-кліматичної зони; типу грунту; складу нафти, що потрапила в грунт. У середньому нижня межа концентрацій нафти в забрудненому грунті змінюється від 0,1 до 1,0 г/кг. Критерієм також може слугувати концентрація, що є вищою 0,05 мг/м³ нафти і нафтопродуктів у воді, профільтрованій через забруднений грунт. Нафтове забруднення створює нову екологічну обстановку, що призводить до глибокої зміни всіх ланок природних біоценозів або їхньої повної трансформації. Загальна особливість всіх нафтозабруднених грунтів - зміна чисельності та обмеження видового різноманіття педобіонтів (грунтової мезофауни та мікрофауни, а також мікрофлори).

Для оцінки екологічного стану грунтового покриву визначається вміст в грунтах забруднювальних речовин і формується відповідна база даних. При екологічних дослідженнях того чи іншого регіону визначається оптимальна 
мережа екологічних полігонів, на яких відбираються проби з грунтового покриву. Приклад цієї бази наведений фрагментами в табл. 1, що знайшло своє відображення на еколого-техногеохімічних картах.

На основі отриманих баз даних (1) були розраховані, за методикою В.М. Гуцуляка [8], сумарні показники забруднення СПЗ як суми відношень вмісту тої чи іншої речовини Сі до фонового вмісту Сф або до ГДК:

$$
\text { СПЗ }=\sum_{n=1}^{i} C i: \text { Сф або } \quad \text { СП }=\sum_{n=1}^{i} C i: \text { ГДК }
$$

ГДК забруднювальних речовин для грунтів відомі, а фонові вмісти розраховувались за методикою О.М. Адаменка [3]. 3 нашої точки зору, СПЗ необхідно визначати не тільки по відношенню до ГДК, а й до фону, тому що регіональний фон вмісту того чи іншого хімічного елементу або речовини більш об'єктивно відображає природне геохімічне поле грунтового покриву. На фоні регіональних вмістів забруднювальних речовин виявляються геохімічні аномалії, які утворюються, якщо фон перевищено не менше, як у 3 рази.

Таблиця 1 - Забруднення грунтів Тернопільської області нафтопродуктами 2018 p.

\begin{tabular}{|c|c|c|c|c|c|c|c|c|}
\hline \multirow[b]{2}{*}{ Область } & \multirow[b]{2}{*}{ Район } & \multicolumn{3}{|c|}{ Кількість проб, штук } & \multicolumn{3}{|c|}{$\begin{array}{c}\text { Вміст забруднювача } \\
\text { мг/кг } \\
\end{array}$} & \multirow[t]{2}{*}{$\begin{array}{l}\text { ГДК, } \\
\text { мГ/кГ }\end{array}$} \\
\hline & & $\begin{array}{l}\text { Проана- } \\
\text { лізовано }\end{array}$ & $\begin{array}{c}3 \text { них } \\
\text { містять } \\
\text { ЗКП } \\
\end{array}$ & $\begin{array}{c}3 \text { них із } \\
\text { вмістом } \\
\text { вище ГДК }\end{array}$ & мін & середн & макс & \\
\hline \multirow{6}{*}{ 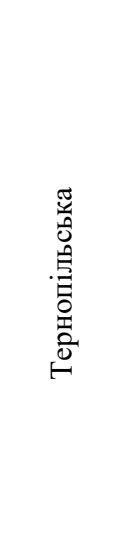 } & \multirow{2}{*}{ 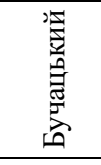 } & 602 & - & не виявл. & 0,02 & 0,20 & 0,63 & 3,0 \\
\hline & & 602 & - & не виявл. & 2,52 & 7,8 & 18,37 & 30 \\
\hline & \multirow{2}{*}{ 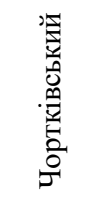 } & 734 & - & не виявл. & 0,02 & 0,23 & 0,77 & 3,0 \\
\hline & & 734 & - & не виявл. & 2,84 & 7,13 & 22,31 & 30 \\
\hline & \multirow{2}{*}{$\begin{array}{l}\text { 罢 } \\
\text { 总 } \\
\text { 兽 } \\
\text { 言 }\end{array}$} & 245 & - & не виявл. & 0,07 & 0,23 & 0,55 & 3,0 \\
\hline & & 245 & - & не виявл. & 2,47 & 7,46 & 12,99 & 30 \\
\hline
\end{tabular}

При еколого-техногеохімічних дослідженнях, з нашої точки зору, важливе значення мають флуктуації фону. Іноді пропонують відносити до фонових вмістів такі, що на гістограмах знаходяться вище 10-відсоткового рівня. 3 врахуванням t-критерія Ст'юдента і величини ймовірності визначають фонові вмісти А.А. Беус, Ю.Е.Сает та ін. Для визначення антропогенного навантаження на грунтовий покрив також пропонується ввести індекс забруднення грунтів (ІЗГ). Для цього необхідно розрахувати коефіцієнти концентрації необхідної кількості забруднюючих речовин в грунтах. Коефіцієнт концентрації $K_{c}$ визначаємо як співвідношення реального вмісту хімічних елементів в грунтах $(C)$ та його гранично допустимої концентрації (рис. 2). 


$$
\begin{array}{r}
\sim 26 \sim \\
K_{c}=\frac{C}{\Gamma Д К} .
\end{array}
$$

Відповідно, ІЗГ буде розрахований за наступною формулою:

$$
I 3 \Gamma=\sum_{i=1}^{n} \frac{K_{C}}{n}
$$

де $n$ - число врахованих елементів, вміст яких перевищує ГДК.

На основі представленої методики можна побудувати картографічну геомодель оцінки якості атмосфери та грунтів в кожній з адміністративних одиниць досліджуваного регіону. Також можна побудувати графік зв'язку ІЗП та ІЗГ та встановити коефіцієнт кореляції даних характеристик. На екологотехногеохімічну карту розповсюдження того чи іншого елемента в конкретному середовищі виносяться ізолінії його рівних концентрацій (ізоконцентрат ik), які повинні відповідати середньому вмісту елемента в кожному характерному інтервалі.

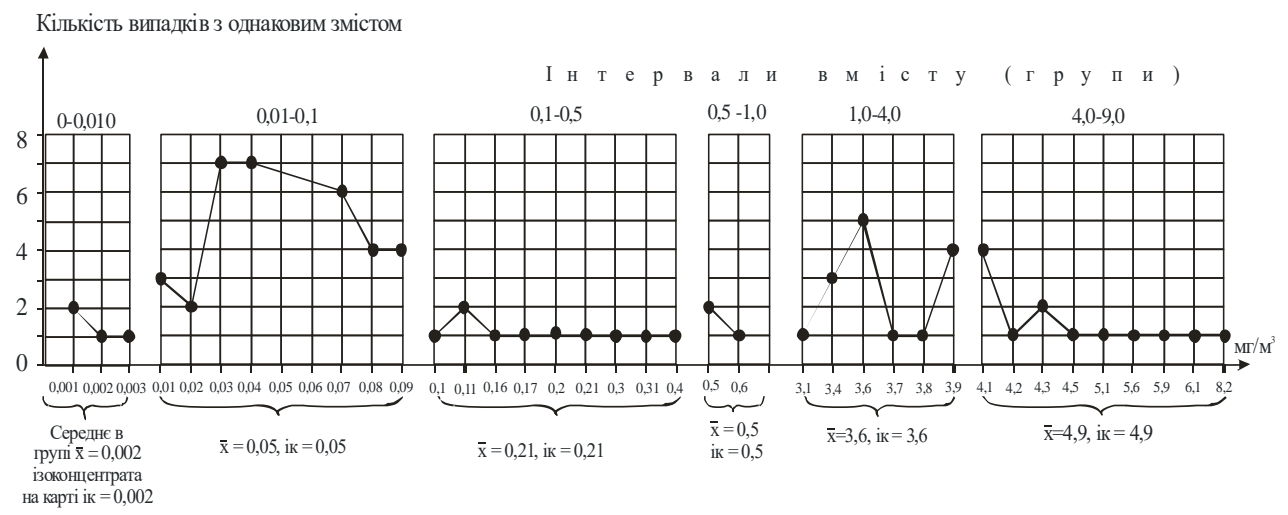

Рис. 1 - Групування вмісту $(C)$ нафтопродуктів в характерних інтервалах (групах) та визначення середнього вмісту (х) в кожному характерному інтервалі (групі) для проведення на карті типових ізоліній однакових концентрацій елементів в грунтах Тернопільської області

Тобто ізолінії концентрацій елементів на картах проводяться не довільно, як іноді можна бачити на геохімічних картах, а тільки через характерні інтервали. Такі ізолінії будуть передавати характер розповсюдження елемента в довкіллі [9] (рис. 3).

Поелементні еколого-техногеохімічні карти вмісту того чи іншого елемента в компонентах ландшафтів будуються шляхом інтерполяції даних від одного екологічного полігону до сусіднього (рис. 3). Для визначення екологічного стану територій запропоновано визначити індекси забруднення атмосфери окремих районів міста, отримані в результаті обробки даних моніторингу методами багатовимірного аналізу. Для полегшення змістовної інтерпретації даних моніторингу та результатів аналізу розроблено систему візуалізації екологічних індексів, які можна безпосередньо наносити на електронну карту, тобто візуалізувати території 3 різним екологічним статусом. Дані екологічного моніторингу й результати обробки представлені у вигляді екологічних карт статистичних поверхонь. 


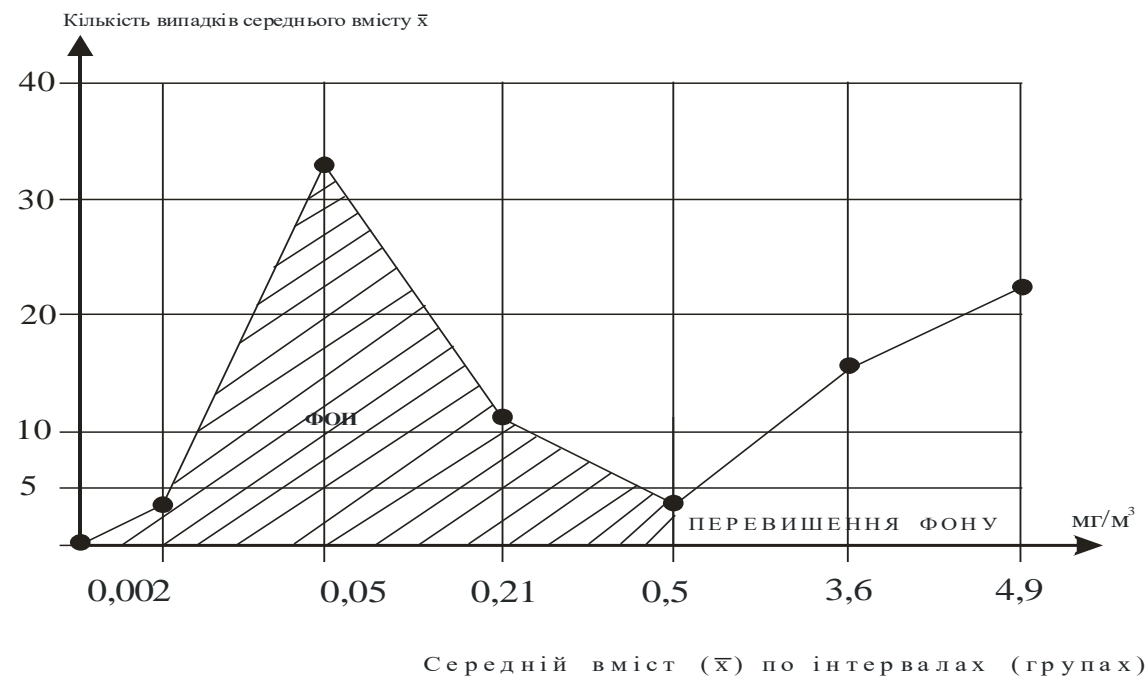

Рис. 2 - Розподіл середніх вмістів ( $\bar{X}$ ) нафтопродуктів по інтервалах (групах) в грунтах Гусятинського району Тернопільської області

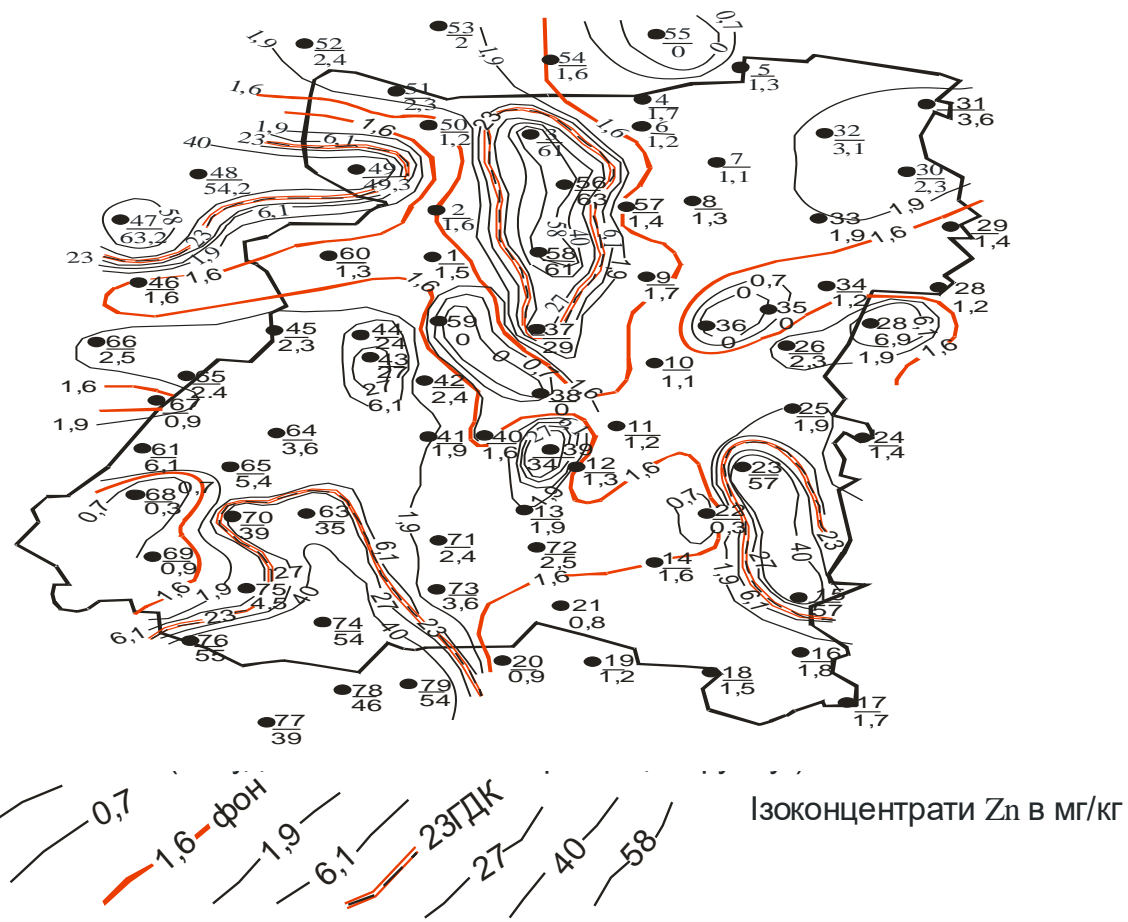

Рис. 3 - Еколого-технохімічна карта вмісту (мг/кг) нафтопродуктів в грунтах Тернопільської області. М 1:100000

Карти, побудовані на основі екологічних індексів, дають найбільш цілісне й інтегроване уявлення про екологічний стан досліджуваної території, оскільки одночасно враховується цілий ряд особливо небезпечних показників [1]. В сфері регіонального моніторингу при визначенні екологічної безпеки методи дистанційного зондування Землі можуть успішно доповнювати наші методики, а в деяких випадках навіть перевершувати їх за інформативністю. 
Зіставлення в ГІС показників розрахункового часу проникнення забруднюючих речовин крізь зону аерації з переважаючим напрямком фізикохімічної міграції хімічних елементів та існуючим рівнем забруднення, дозволяє визначити різний ступінь ризику забруднення грунтів та прогнозувати їх забруднення.

\section{Висновки і пропозиції}

Вдосконалено методику екологічного моніторингу забруднення педосфери нафтопродуктами. Розроблена методика дозволяє ефективно оцінити стан досліджуваної території, враховує особливості як рівня дослідження, так і досліджуваної ділянки. Гнучкість нової системи дозволяє отримувати більшу кількість адекватної інформації.

\section{СПИСОК ЛІТЕРАТУРИ}

1. V. Trysnyuk, T. Trysnyuk, V. Okhariev, V. Shumeiko, A. Nikitin Cartographic Models of Dniester River Basin Probable Flooding Centrul Universitar Nord Din Bala Mare UTPRESS ISSN 1582-0548, №1, 2018, C. 61-67.

2. Греков Л.Д., Красовський Г.Я., Трофимчук О.М. Космічний моніторинг забруднення земель техногенним пилом. Київ. Наукова думка. 2007. - 219 с.

3. Адаменко О. М. Екологічна безпека територій. Монографія / О. М. Адаменко, Я. О. Адаменко, Л. М. Архипова та ін. - Івано-Франківськ : Супрун, 2014. - 456 с.

4. Триснюк В.М. Система управління екологічною безпекою природних i антропогенно-модифікованих геосистем. Системи обробки інформації. - 2016. - №12. - C. 185-188. Index Copernicus

5. Kosenko, V.V. and Kuchuk, N.H. (2016), "Vzayemodiya tekhnichnykh I prohramnykh zasobiv pry upravlinni rozpodilom trafika" ["The interaction of hardware and software in the management of traffic distribution"], Systemy ozbroyennya I viys'kova tekhnika ["Systems of Arms and Military Equipment"], No. 3 (47), pp. 72-75.

6. Myrontsov, M.L. [2019] The problem of equivalence in inverse electrometry problems of oil and gas wells. 18th International Conference Geoinformatics - Theoretical and Applied Aspects, Extended Abstracts.

7. Trofymchuk, O., Kalyukh, Y., Hlebchuk, H. [2013] Mathematical and GIS-modeling of landslides in Kharkiv region of Ukraine. Landslide Science and Practice: Spatial Analysis and Modelling. - Springer, Berlin, Heidelberg. 347-352.

8. Trofymchuk, O., Kreta, D., Myrontsov, M., Okhariev, V., Shumeiko, V., Zagorodnia, S. [2015] Information Technology in Environmental Monitoring for Territorial System Ecological Assessment. Journal of Environmental Science and Engineering. A4, 79-84.

9. Trysnyuk, V.M., Okhariev, V.O., Trysnyuk, T.V., Zorina, O.V., Kurylo, A.V., Golovan, Y.V., Smetanin, K.V., Radlowska, K.O. [2019] Improving the algorithm of satellite images landscape interpretation. 18th International Conference Geoinformatics - Theoretical and Applied Aspects, Extended Abstracts

Стаття надійшла до редакції 23.01.2020 і прийнята до друку після рецензування 06.04.2020

\section{REFERENCES}

1. Trysnyuk, V., Trysnyuk, T., Okhariev, V., Shumeiko, V., \& Nikitin, A. (2018). Cartographic Models of Dniester River Basin Probable Flooding. Centrul Universitar Nord Din Bala Mare - UTPRESS, 1, 61-67. 
2. Grekov, L.D., Krasovsky, G.Y., \& Trofimchuk, O.M. (2007). Space monitoring of land pollution by man-made dust. Kiev: Naukova dumka. (in Ukrainian)

3. Adamenko, O.M., Adamenko, Y.A., Arkhipova, L.M. et al. (2014). Ecological safety of territories. Ivano-Frankivsk: Suprun. (in Ukrainian)

4. Trisnyuk, V.M. (2016). Environmental safety management system for natural and anthropogenically modified geosystems. Information processing systems, 12, 185-188. (in Ukrainian)

5. Kosenko, V.V. \& Kuchuk, N.H. (2016). Vzayemodiya tekhnichnykh I prohramnykh zasobiv pry upravlinni rozpodilom trafika [The interaction of hardware and software in the management of traffic distribution]. Systemy ozbroyennya I viys'kova tekhnika [Systems of Arms and Military Equipment], 3(47), 72-75. (in Ukrainian)

6. Myrontsov, M.L. (2019). The problem of equivalence in inverse electrometry problems of oil and gas wells: 18th International Conference Geoinformatics - Theoretical and Applied Aspects, Extended Abstracts.

7. Trofymchuk, O., Kalyukh, Y., \& Hlebchuk, H. (2013). Mathematical and GIS-modeling of landslides in Kharkiv region of Ukraine. Landslide Science and Practice: Spatial Analysis and Modelling, 347-352. Springer, Berlin, Heidelberg.

8. Trofymchuk, O., Kreta, D., Myrontsov, M., Okhariev, V., Shumeiko, V., \& Zagorodnia, S. (2015). Information Technology in Environmental Monitoring for Territorial System Ecological Assessment. Journal of Environmental Science and Engineering, A4, 79-84.

9. Trysnyuk, V.M., Okhariev, V.O., Trysnyuk, T.V., Zorina, O.V., Kurylo, A.V., Golovan, Y.V., Smetanin, K.V., \& Radlowska, K.O. (2019). Improving the algorithm of satellite images landscape interpretation: 18th International Conference Geoinformatics Theoretical and Applied Aspects, Extended Abstracts.

The article was received 23.01.2020 and was accepted after revision 06.04.2020

\section{Триснюк Василь Миколайович}

доктор технічних наук, старший науковий співробітник, завідувач відділу досліджень навколишнього середовища Інституту телекомунікацій і глобального інформаційного простору НАН України

Робоча адреса: 03186, м. Київ, Чоколівський бульвар, 13

ORCID ID: 0000-0001-9920-4879e-mail: trysnyuk@ukr.net

\section{Охарєв Вячеслав Олександрович}

кандидат технічних наук, старший науковий співробітник Інституту телекомунікацій і глобального інформаційного простору НАН України

Робоча адреса: 03186, м. Київ, Чоколівський бульвар, 13

ORCID ID: 0000-0001-6270-6293 e-mail: okhariev.vo@gmail.com

\section{Триснюк Тарас Васильович}

кандидат технічних наук, науковий співробітник Інституту телекомунікацій i глобального інформаційного простору НАН України

Робоча адреса: 03186, м. Київ, Чоколівський бульвар, 13

ORCID ID: 0000-0002-3672-8242 e-mail: trysnyuktaras@ukr.net

\section{Голован Юрій Миронович}

аспірант Інституту телекомунікацій і глобального інформаційного простору НАН України

Робоча адреса: 03186, м. Київ, Чоколівський бульвар, 13

ORCID ID: 0000-0001-7050-9310e-mail: dirrecta@gmail.com 